\title{
A role for alternative pathway catecholamines in the regulation of steroidogenesis in cow luteal cells
}

\author{
P. J. Battista and W. A. Condon \\ Department of Animal and Nutritional Sciences, The University of New Hampshire, Durham, \\ New Hampshire 03824, U.S.A.
}

\begin{abstract}
Summary. Incubation of bovine luteal cells with the alternative pathway catecholamines octopamine, synephrine and deoxyadrenaline at concentrations of $10^{-6}$ to $10^{-3} \mathrm{M}$ enhanced the production of progesterone $(P<0.05)$. Tryamine did not alter basal progesterone production $(P>0.05)$. Addition of noradrenaline and adrenaline at concentrations of $10^{-4}$ to $10^{-7} \mathrm{M}$ significantly elevated the production of progesterone $(P<0.05)$. The steroidogenic response to noradrenaline and adrenaline was greater than that for octopamine, synephrine and deoxyadrenaline $(P<0 \cdot 05)$. Response to both primary $\left(10^{-6} \mathrm{M}\right)$ and alternative $\left(10^{-4} \mathrm{M}\right)$ pathway catecholamines was inhibited by propranolol $\left(10^{-5} \mathrm{M}, P<0.05\right)$ but not phentolamine $\left(10^{-5} \mathrm{M}\right.$, $P>0.05)$. These results demonstrate that octopamine, synephrine and deoxyadrenaline can affect steroidogenesis by bovine luteal cells, and their action is mediated by $\beta$-adrenergic receptors.
\end{abstract}

\section{Introduction}

The primary catecholamines noradrenaline and adrenaline can regulate the synthesis in vitro of cAMP and progesterone by luteal tissue from a variety of species (cow: Condon \& Black, 1976; Godkin, Black \& Duby, 1977; Milvae, Alila \& Hansel, 1983; rat: Harwood, Dufau \& Catt, 1979; Ratner, Sanborn \& Weiss, 1980; Norjavaara, Selstam \& Ahren, 1982; rabbit: Birnbaumer, Yang, Hunzicker-Dunn, Brockaert \& Duran, 1976; ewe: Jordan, Caffrey \& Niswender, 1978). Noradrenaline and adrenaline can interact with both $\alpha$ - and $\beta$-adrenergic receptors although their stimulatory effects on luteal steroidogenesis are mediated by $\beta$-receptors, since their response can be inhibited by $\beta$-adrenergic antagonists but not by $\alpha$-adrenergic antagonists (Condon \& Black, 1976; Jordan et al., 1978; Harwood, Richert, Dufau \& Catt, 1980; Ratner et al., 1980; Norjavaara et al. 1982). In contrast, nothing is known about the catecholamines derived through the alternative catecholamine pathway (Fig. 1) with respect to ovarian steroidogenesis. Octopamine and synephrine have been identified within the central nervous system and peripheral tissues in a number of vertebrate species (Kakimoto \& Armstrong, 1962; Molinoff \& Axelrod, 1969, 1972; Saavedra, 1974; Harmar \& Horn, 1976). In peripheral tissues octopamine is associated with sympathetic nerve endings (Molinoff \& Axelrod, 1969, 1972) where it can be taken-up, synthesized and stored (Fischer, Musacchio, Kopin \& Axelrod, 1964; Kopin, Fischer, Musacchio \& Horst, 1964; Kopin, Fischer, Musacchio, Horst \& Weise, 1965; Baldessarini \& Vogt, 1971). Octopamine accumulates in sympathetic nerves after monoamine oxidase inhibition and is released following neural stimulation (Kopin et al., 1964, 1965; Fischer, Horst \& Kopin, 1965; Baldessarini, 1971; Baldessarini \& Vogt, 1972). Additionally, octopamine has a subcellular distribution similar to that of noradrenaline (Musacchio, Kopin \& Snyder, 1964; Snyder, Michaelson \& Musacchio, 1964; Snyder, Glowinski \& Axelrod, 1965; Baldessarini \& Vogt, 1971; Molinoff \& Axelrod, 1972), and a physiological role for octopamine as a cotransmitter with noradrenaline has been proposed (Molinoff \& Axelrod, 1969, 1972; Axelrod \& Saavedra, 1977). 


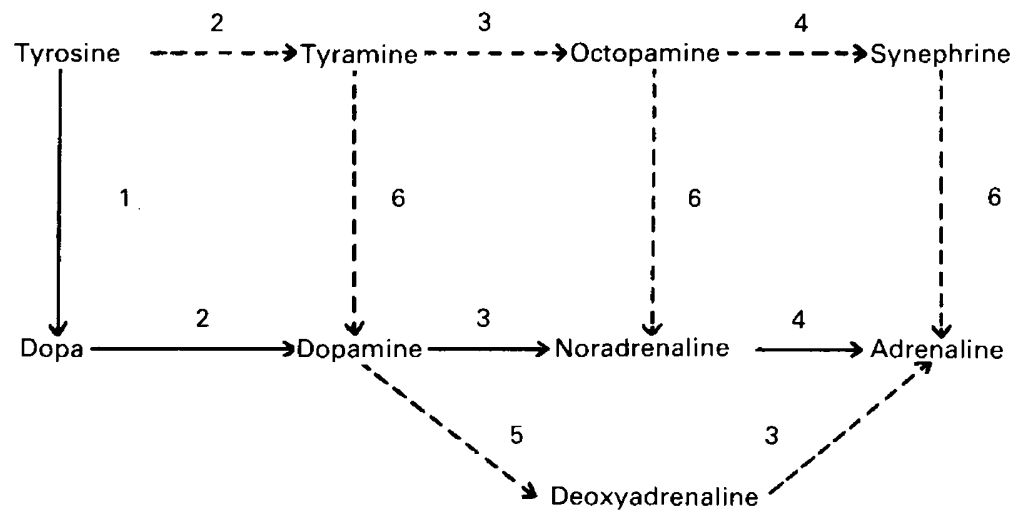

Fig. 1. Primary and alternative pathways for the formation of catecholamines: (1) tyrosine hydroxylase; (2) aromatic aminoacid decarboxylase; (3) dopamine- $\beta$-oxidase; (4) phenylethanolamine- $N$-methyl transferase; (5) nonspecific $N$-methyltransferase; (6) catecholforming enzyme. Solid lines denote primary pathway. (Modified from Axelrod, 1963; and Cooper, Bloom \& Roth, 1982).

The physiological significance of the alternative pathway catecholamines with respect to luteal function is unknown. It was the purpose of this study to examine the ability of the alternative pathway catecholamines tyramine, octopamine, synephrine and deoxyadrenaline to regulate steroidogenesis by bovine luteal cells.

\section{Materials and Methods}

\section{Materials, drug description and preparation}

Tyramine $\mathrm{HCl}$, DL-octopamine $\mathrm{HCl}$, DL-synephrine, deoxyadrenaline $\mathrm{HCl}$, L-noradrenaline $\mathrm{HCl}$, DL-adrenaline and DL-propranolol $\mathrm{HCl}$ were purchased from Sigma Chemical Co., St Louis, MO. Phentolamine $\mathrm{HCl}$ was donated by Ciba-Geigy Corp., Summit, NJ. Ham's F12 culture medium was purchased from Grand Island Biological Co., Grand Island, NY. The collagenase was Worthington, Type 1, Freehold, NJ, and $N$-2-hydroxythylpiperazine- $N$-2-ethanesulphonic acid (Hepes) was purchased from Calbiochem-Behring, San Diego, CA.

Propranolol is a nonspecific $\beta$-adrenergic receptor antagonist and phentolamine is a nonspecific $\alpha$-adrenergic antagonist. All hormones and drugs were prepared in cold $0.05 \mathrm{M}$-phosphate-buffered saline (pH 7.2) before use in each experiment. In all cases $\mathrm{N}$ equals the number of animals tested. Duplicate determination of all treatments was performed for each corpus luteum.

\section{Experimental procedures}

Corpora lutea (CL) were obtained per vaginam from regularly cycling, nonlactating dairy cows on Days 10-12 of the oestrous cycle (oestrus = Day 0). Luteal tissue was placed into Ham's F12 culture medium containing $24 \mathrm{~mm}-$ Hepes $\left(\mathrm{pH} \mathrm{7.4)}\right.$ at $4^{\circ} \mathrm{C}$ for transport to the laboratory. Luteal tissue was dissociated with collagenase $(2000 \mathrm{u} / \mathrm{g}$ tissue) and cell number and viability were determined as described by Pate \& Condon (1982). Incubations were conducted utilizing $2.5 \times 10^{5}$ viable cells in a final volume of $1 \mathrm{ml} \mathrm{Ham}$ 's F12 culture medium and incubated for $2 \mathrm{~h}$ at $37^{\circ} \mathrm{C}$ as previously described (Battista \& Condon, 1986). Tyramine, octopamine, synephrine and deoxyadrenaline were added to luteal cell suspensions at a final concentration of $10^{-6}$ to $10^{-3} \mathrm{M}$. Noradrenaline and adrenaline were tested at $10^{-7}$ to $10^{-4} \mathrm{M}$. For determination of the adrenergic receptor mediating the catecholamine response, noradrenaline and adrenaline $\left(10^{-6} \mathrm{M}\right)$ or 
octopamine, synephrine and deoxyadrenaline $\left(10^{-4} \mathrm{M}\right)$ were added to incubations which had been preincubated for $30 \mathrm{~min}$ with propranolol $\left(10^{-5} \mathrm{M}\right)$ or phentolamine $\left(10^{-5} \mathrm{M}\right)$.

Progesterone in the incubation medium was quantitated by radioimmunoassay of unextracted samples using antiprogesterone-11-bovine serum albumin (No. 337, Niswender). The progesterone tracer used was $\left[1,2-{ }^{3} \mathrm{H}\right]$ progesterone (New England Nuclear, Boston, MA). The sensitivity of the assay, as determined by the lower $95 \%$ confidence limit of the maximum binding in the absence of any unlabelled progesterone, was $0.1 \mathrm{ng}$. The intra-assay and interassay coefficients of variability were $7 \cdot 3 \%$ and $12.4 \%$ respectively. All standards were assayed in quadruplicate, and all unknowns were assayed in duplicate.

\section{Statistical analysis}

Analysis of difference between treatment means was conducted using one-way analysis of variance followed by the Student-Newman-Keuls mean separation procedure.

\section{Results}

Luteal steroidogenesis in the presence of alternative pathway catecholamines is shown in Fig. 2(a). Octopamine, synephrine and deoxyadrenaline significantly enhanced progesterone production at

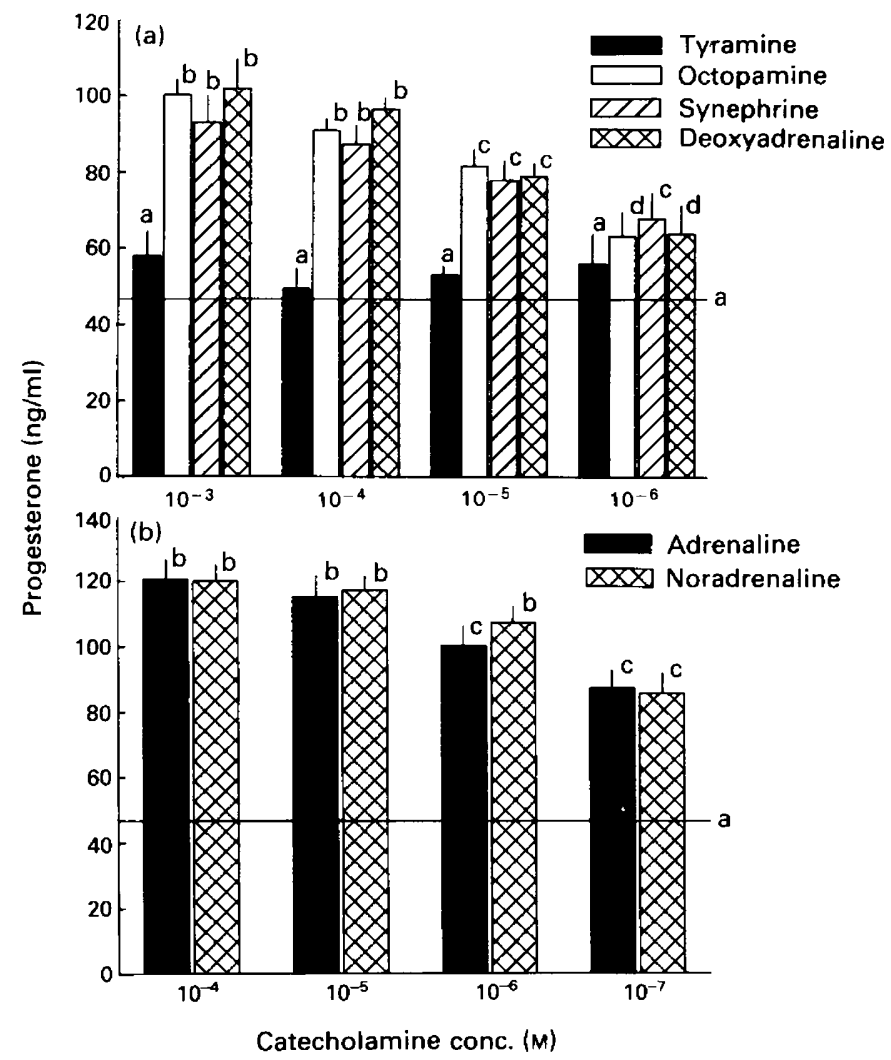

Fig. 2. Effect of (a) alternative pathway catecholamines and (b) noradrenaline and adrenaline on progesterone production by dissociated luteal cells. Data are expressed as the mean \pm s.e.m. $(\mathrm{N}=6$ for all treatments). Solid line denotes control value of $46 \cdot 4 \pm 2 \cdot 13 \mathrm{ng} / \mathrm{ml}$. Bars within treatments with different superscript letters are significantly different $(P<0.05)$. 
concentrations of $10^{-6}$ to $10^{-3} \mathrm{M}(P<0 \cdot 05)$. Tyramine was ineffective in regulating the production of progesterone $(P>0.05)$. The response to octopamine, synephrine and deoxyadrenaline was similar within each treatment concentration. Addition of noradrenaline and adrenaline at $10^{-7}$ to $10^{-4} \mathrm{M}$ resulted in a significant elevation in the production of progesterone $(P<0 \cdot 05$, Fig. $2(\mathrm{~b}))$. Comparison of the response of luteal cells to primary and alternative pathway catecholamines showed that noradrenaline and adrenaline were more potent agonists than were octopamine, synephrine or deoxyadrenaline $(P<0.05)$. The stimulatory effects of noradrenaline and adrenaline $\left(10^{-6} \mathrm{M}\right)$ and of octopamine, synephrine and deoxyadrenaline $\left(10^{-4} \mathrm{M}\right)$ were inhibited by propranolol $\left(10^{-5} \mathrm{M}, P<0.05\right.$, Table 1$)$ but not by phentolamine $\left(10^{-5} \mathrm{M}, P>0.05\right)$. Neither propranolol nor phentolamine significantly altered basal progesterone production (data not shown).

Table 1. Effect of $\alpha$ - and $\beta$-adrenergic antagonists on primary and alternative pathway catecholamineinduced progesterone production $(\mathrm{ng} / \mathrm{ml}$ incubation medium)

\begin{tabular}{lcccccc}
\hline & $\mathrm{N}$ & Octopamine & Synephrine & Deoxyadrenaline & Noradrenaline & Adrenaline \\
\hline $\begin{array}{l}\text { Agonist alone } \\
\text { Agonist }+\end{array}$ & 6 & $90 \cdot 6 \pm 2 \cdot 25^{\mathrm{a}}$ & $87 \cdot 4 \pm 4 \cdot 81^{\mathrm{a}}$ & $96 \cdot 5 \pm 1 \cdot 92^{\mathrm{a}}$ & $99 \cdot 9 \pm 6 \cdot 61^{\mathrm{a}}$ & $107 \cdot 2 \pm 4 \cdot 07^{\mathrm{a}}$ \\
$\begin{array}{c}\text { propranolol } \\
\begin{array}{c}\text { Agonist }+ \\
\text { phentolamine }\end{array}\end{array}$ & 4 & $57 \cdot 8 \pm 8 \cdot 54^{\mathrm{b}}$ & $61 \cdot 4 \pm 5 \cdot 77^{\mathrm{b}}$ & $52 \cdot 3 \pm 6 \cdot 18^{\mathrm{b}}$ & $55 \cdot 5 \pm 3 \cdot 30^{\mathrm{b}}$ & $63 \cdot 8 \pm 6 \cdot 64^{\mathrm{b}}$ \\
\hline
\end{tabular}

Values are mean \pm s.e.m.

Means within columns with different superscript letters are significantly different $(P<0 \cdot 05)$.

Control value equals $46 \cdot 4 \pm 2 \cdot 13$.

\section{Discussion}

These results demonstrate a regulatory role for the alternative pathway catecholamines octopamine, synephrine and deoxyadrenaline in the control of bovine luteal steroidogenesis. The stimulatory effects of noradrenaline and adrenaline on progesterone production and the ability of the $\beta$ adrenergic antagonist propranolol to inhibit this response is consistent with previous results (Condon \& Black, 1976; Jordan et al., 1978; Harwood et al., 1980; Ratner et al., 1980; Norjavaara et al., 1982). In other mammalian tissues octopamine has been reported to interact with $\alpha$ - and $\beta$-adrenergic receptors (Fujiwara, Keisuke, Hideo, Takashi \& Yoshiko, 1968), exclusively with $\alpha$ receptors (Kelly \& Burks, 1974; Kleinrok, 1979) or exclusively with $\beta$-adrenergic receptors (Chiba, 1976). The ability of propranolol but not phentolamine to inhibit the steroidogenic response to octopamine, synephrine and deoxyadrenaline suggests that their action is mediated by $\beta$-adrenergic receptors. The lower potency observed for the alternative pathway catecholamines with respect to progesterone production is similar to that reported for their ability to regulate other physiological processes (Lands \& Grant, 1952; Fujiwara et al., 1968; Nedergaard \& Westermann, 1968; Kelly \& Burks, 1974).

The mammalian ovary is extensively innervated with adrenergic and cholinergic nerve fibres, although the $\mathrm{CL}$ appears to be devoid of any direct neural innervation (Bahr, Kao \& Nalbandov, 1974; Burden, 1978; Stefenson, Owman, Sjoberg, Sporrong \& Walles, 1981). No data are presently available to suggest that the bovine CL can synthesize or retain catecholamines. HPLC analysis of bovine luteal tissue did not reveal noradrenaline or adrenaline to be present in early, mid or late cycle CL (P. J. Battista, C. Rexroad \& W. A. Condon, unpublished observations). The failure to identify these catecholamines in bovine luteal tissue may suggest that the steroidogenic action of octopamine, synephrine and deoxyadrenaline is not due to conversion to primary catecholamines. 
Additionally, the inability of tyramine to stimulate luteal steroidogenesis may suggest that the enzymes responsible for primary and alternative pathway catecholamine synthesis are not present in bovine luteal tissue.

The mechanism whereby catecholamines regulate progesterone production in the cow CL is unknown. In rat granulosa cells, adrenergic agents increase the enzymic activity of $3 \beta$-hydroxysteroid dehydrogenase while decreasing $20 \alpha$-hydroxysteroid dehydrogenase activity (Hsueh et al., 1983). Ovarian denervation or chemical sympathectomy decreases $3 \beta$-hydroxysteroid dehydrogenase activity in the rat $\mathrm{CL}$, suggesting that catecholamines may regulate steroidal enzyme activity in vivo (Burden, 1978).

In summary, these results demonstrate that the alternative pathway catecholamines octopamine, synephrine and deoxyadrenaline stimulate steroid biosynthesis in bovine luteal tissue in vitro. The response to these catecholamines is less than that observed for noradrenaline and adrenaline, and the steroidogenic response of octopamine, synephrine and deoxyadrenaline is mediated by $\beta$-adrenergic receptors.

Scientific Contribution No. 1406 from the New Hampshire Agricultural Experiment Station. We thank Dr G. D. Niswender for the progesterone antiserum and D. Stranger for manuscript preparation. This research was a contribution to Northeast Regional Project NE-72.

\section{References}

Axelrod, J. (1963) Enzymatic formation of adrenaline and other catechols from monophenols. Science, N.Y. 140, 499-500.

Axelrod, J. \& Saavedra, J.M. (1977) Octopamine. Nature, Lond. 265, 501-504.

Bahr, J., Kao, L. \& Nalbandov, A.V. (1974) The role of catecholamines and nerves in ovulation. Biol. Reprod. 10, 273-290.

Baldessarini, R.J. (1971) Release of aromatic amines from brain tissues of the rat in vitro. J. Neurochem. 18, 2509-2518.

Baidessarini, R.J. \& Vogt, M. (1971) The uptake and subcellular distribution of aromatic amines in the brain of the rat. J. Neurochem. 18, 2519-2533.

Baldessarini, R.J. \& Vogt, M. (1972) Regional release of aromatic amines from tissues of the rat brain in vitro. J. Neurochem. 19, 755-761.

Battista, P.J. \& Condon, W.A. (1986) Serotonin-induced stimulation of progesterone production by cow luteal cells in vitro. J. Reprod. Fert. 76, 231-238.

Birnbaumer, L., Yang, P.C., Hunzicker-Dunn, M., Brockaert, J. \& Duran, J.M. (1976) Adenyl cyclase activities in ovarian tissues. I. Homogenization and conditions of assay in Graffian follicles and corpora lutea of rabbits, rats and pigs: regulation by ATP, and some comparative properties. Endocrinology 99, 163-184.

Burden, H.W. (1978) Ovarian innervation. In The Vertebrate Ovary, pp. 615-638. Ed. R. E. Jones. Plenum Press, New York.

Chiba, S. (1976) Pharmacologic analysis of positive chronotropic and inotropic responses to octopamine. Tohoku J. exp. Med. 118, 247-253.

Condon, W.A. \& Black, D.L. (1976) Catecholamineinduced stimulation of progesterone by the bovine corpus luteum in vitro. Biol. Reprod. 15, 573-578.

Cooper, J.R., Bloom, F.E. \& Roth, R.H. (1982) Catecho- lamines I: General aspects. In The Biochemical Basis of Neuropharmacology, pp. 109-172. Oxford University Press, New York.

Fischer, J.E., Musacchio, J., Kopin, I.J. \& Axelrod, J.. (1964) Effects of denervation on the uptake and $\beta$ hydroxylation of tyramine in the rat salivary gland. Life Sci. 3, 413-419.

Fischer, J.E., Horst, W.D. \& Kopin, I.J. (1965) $\beta$ Hydroxylated sympathomimic amines as false neurotransmitters. Br. J. Pharmacol. Chemother. 24, $477-484$.

Fujiwara, M., Keisuke, H., Hideo, M., Takashi, M. \& Yoshiko, K. (1968) Pharmacological action of octopamine with special reference to biochemical conversion to noradrenaline. Jap. J. Pharmacol. 18, $113-129$.

Godkin, J.D., Black, D.L. \& Duby, R.T. (1977) Stimulation of cyclic AMP and progesterone synthesis by $\mathrm{LH}, \mathrm{PGE}_{2}$ and isoproterenol in the bovine $\mathrm{CL}$ in vitro. Biol. Reprod. 17, 514-518.

Harmar, A.J. \& Horn, A.S. (1976) Octopamine in mammalian brain: rapid post mortem increase and effects of drugs. J. Neurochem. 26, 987-993.

Harwood, J.P., Dufau, M.L. \& Catt, K.J. (1979) Differing specificities of ovarian cyclase by epinephrine and human chorionic gonadotropin. Molec. Pharmacol. 15, 439-444.

Harwood, J.P., Richert, N.D., Dufau, M.L. \& Catt, K.J. (1980) Gonadotropin-induced desensitization of epinephrine action in the luteinized rat ovary. Endocrinology 107, 280-288.

Hsueh, A.J.W., Jones, P.B.C., Adashi, E.Y., Wang, C., Zhuang, L.Z. \& Welsh, T.H., Jr (1983) Intraovarian mechanisms in the hormonal control of granulosa cell differentiation in rats. J. Reprod. Fert. 69, 325-342.

Jordan, A.W., III, Cafirey, J.L. \& Niswender, G.D. 
(1978) Catecholamine-induced stimulation of progesterone and adenosine $3^{\prime}, 5^{\prime}$-monophosphate production by dispersed ovine luteal cells. Endocrinology 103, 385-392.

Kakimoto, Y. \& Armstrong, M.D. (1962) On the identification of octopamine in mammals. J. biol. Chem. 237, $422-427$.

Kelly, R.J. \& Burks, T.F. (1974) Relative vasoconstrictive potencies of norepinephrine, alpha-methyl-norepinephrine and octopamine. Arch. Int. Pharmacodyn. Ther. 208, 306-316.

Kleinrok, Z. (1979) Central effects of octopamine administered into the lateral ventricle of rats. Acta physiol. pol. 30, 445-454.

Kopin, I.J., Fischer, J.E., Musacchio, J. \& Horst, W.D. (1964) Evidence for a false neurochemical transmitter as a mechanism for the hypotensive effect of monoamine oxidase inhibitors. Proc. natn. Acad. Sci. U.S.A. 52, 716-721.

Kopin, I.J., Fischer, J.E., Musacchio, J., Horst, W.D. \& Weise, V.K. (1965) False neurochemical transmitters and the mechanism of sympathetic blockage by monoamine oxidase inhibitors. J. Pharmacol. exp. Ther. 147, 186-193.

Lands, A.M. \& Grant, J.I. (1952) The vasopressor action and toxicity of cyclohexylethylamine derivatives. $J$. Pharmacol. exp. Ther. 106, 341-345.

Milvae, R.A., Alila, H.W. \& Hansel, W. (1983) Methylation in bovine luteal cells as a regulator of luteinizing hormone action. Biol. Reprod. 29, 849-855.

Molinoff, P. \& Axelrod, J. (1969) Octopamine: normal occurrence in sympathetic nerves of rats. Science, N.Y. 164, 428-429.

Molinoff, P.B. \& Axelrod, J. (1972) Distribution and turnover of octopamine in tissues. J. Neurochem. 19, 157-163.
Musacchio, J., Kopin, I.J. \& Snyder, S. (1964) Effects of disulfiram on tissue norepinephrine content and subcellular distribution of dopamine, tyramine and their $\beta$-hydroxylated metabolites. Life Sci. 3, 769-775.

Nedergaard, O.A. \& Westermann, E. (1968) Action of various sympathetic amines on the isolated stripped vas deferens of the guinea pig. Br. J. Pharmacol. 34, $475-483$.

Norjavaara, E., Selstam, G. \& Ahren, K. (1982) Catecholamine stimulation of cyclic AMP and progesterone production in rat corpora lutea of different ages. Acta endocr., Copenh. 100, 613-622.

Pate, J.L. \& Condon, W.A. (1982) Effect of serum and lipoproteins on steroidogenesis in cultured bovine luteal cells. Molec. cell. Endocr. 28, 551-562.

Ratner, A., Sanborn, C.R. \& Weiss, G.K. (1980) $\beta$ adrenergic stimulation of cAMP and progesterone in rat ovarian tissue. Am. J. Physiol. 239, E139-E143.

Saavedra, J.M. (1974) Enzymatic-isotope method for octopamine at the picogram level. Analyt. Biochem. 59, 628-633.

Snyder, S.H., Michaelson, I.A. \& Musacchio, J. (1964) Purification of norepinephrine storage granules from rat heart. Life Sci. 3, 965-970.

Snyder, S.H., Glowinski, J. \& Axelrod, J. (1965) The storage of norepinephrine and some of its derivatives in brain synaptosomes. Life Sci. 4, 797-807.

Stefenson, A., Owman, Ch., Sjoberg, N.O., Sporrong, B. \& Walles, B. (1981) Comparative study of the autonomic innervation of the mammalian ovary, with particular regard to the follicular system. Cell Tissue Res. 215, 47-62. 